\title{
The New Trend of Trade Protectionism in the Post-Financial Crisis Era and Countermeasures of China
}

\author{
Zhongqi Hua \\ School of Business, Nanjing Normal University, Nanjing, China \\ Email: huazhongqi123@sina.com
}

How to cite this paper: Hua, Z.Q. (2019) The New Trend of Trade Protectionism in the Post-Financial Crisis Era and Countermeasures of China. Open Journal of Social Sciences, 7, 58-69.

https://doi.org/10.4236/jss.2019.78005

Received: July 5, 2019

Accepted: August 6, 2019

Published: August 9, 2019

Copyright (อ 2019 by author(s) and Scientific Research Publishing Inc. This work is licensed under the Creative Commons Attribution International License (CC BY 4.0).

http://creativecommons.org/licenses/by/4.0/

\begin{abstract}
Based on database of trade protection measures of GTA (Global Trade Alert), this paper attends to analyze the new trend of trade protectionism in the post-financial crisis era as well as the protection measures that China faced with. The analyzing results appeal that the number of trade protection measures increase rapidly with several new features, which reflects a new trend of global trade protectionism. China is the biggest victim in face of it. In respond to New Trade Protectionism, the paper proposes countermeasures in five respects.
\end{abstract}

\section{Keywords}

Post-Financial Crisis Era, New Trade Protectionism, Trade Barriers

\section{Introduction}

The global financial crisis that erupted in 2008 has been more than 10 years, but its far-reaching impact on the world economy still exists. In the past ten years, all countries have been striving to eliminate the damage caused by the financial crisis to their own economies. In this process, the world's economic and trade pattern has undergone tremendous changes. Countries around the world have built up trade barriers and held high the banner of trade protection to safeguard their national interests. The trend of "new trade protectionism" has begun to rise, and the prospects for the process of economic globalization have become uncertain. In the process of global economic recovery and global value chain reconstruction after the financial crisis, China, as a representative of emerging economies, actively promoted deepening reform and reform and opening, vigorously developed foreign trade, and gradually became the world's largest trader 
of goods. At the same time, China has also become a "public target" for trade protection in major economies, including developed and developing countries (WTO, 2010) [1].

At present, the road to recovery of the global economy is not smooth, which determines that the impact of new trade protectionism on China will exist for a long time. Therefore, the characteristics and trends of the post-financial crisis era world and the trade protection measures against China not only help to better cope with the endless and complicated trade frictions, but also formulate coping strategies and help stabilize and expand. China's exports will strengthen the growth momentum of China's export trade during the deep-water period of reform and opening. Based on the Global Trade Alert's Global Trade Database, this paper systematically describes the new characteristics and trends of world trade protectionism in the post-financial crisis era, and proposes China's response strategies accordingly.

The GTA database is divided into three categories for each trade protection measure based on its impact on foreign commercial interests: Red, Amber, and Green. Table 1 shows the three-color coded classification standard interpretation.

After the financial crisis broke out, trade protectionism came back. Table 2 shows that trade protectionism has not converged with the end of the financial crisis, but has remained at a high level in 2009 for several years, peaked in 2015, and then declined. The trend of the number of yellow and red measures involving discrimination against foreign commercial interests is also roughly the same, with more than 1200 tariff lines affected.

It is worth noting that among these measures, the measures coded in red each year account for the majority, meaning that most countries take more proactive measures to violate the interests of other countries to implement trade protectionism rather than passively responding. Trade protection measures in other countries.

Table 1. Color coding of protectionist measures in the database.

\begin{tabular}{l} 
Color coding Criteria \\
\hline Red \\
The measure has been implemented and almost certainly discriminates against \\
foreign commercial interests. \\
1) The measure has been implemented and may involve discrimination \\
against foreign commercial interests; OR \\
2) The measure has been announced or is under consideration and would \\
(if implemented) almost certainly involve discrimination against \\
foreign commercial interests. \\
1) The measure has been announced and involves liberalization on a \\
nondiscriminatory (i.e., most favored nation) basis; OR \\
2) The measure has been implemented and is found (upon investigation) \\
not to be discriminatory: OR \\
3) The measure has been implemented, involves no further discrimination, \\
and improves the transparency of a jurisdiction's trade-related policies.
\end{tabular}

Note: The 1st GTA Report, 2009 [2]. 
Table 2. The number of global trade protection measures (2009-2017).

\begin{tabular}{cccccccccc}
\hline & 2009 & 2010 & 2011 & 2012 & 2013 & 2014 & 2015 & 2016 & 2017 \\
\hline Green & 10,140 & 9233 & 12,921 & 16,539 & 13,608 & 12,691 & 15,172 & 11,895 & 9895 \\
Amber & 3999 & 1740 & 3136 & 1928 & 3160 & 4252 & 3537 & 2514 & 1809 \\
Red & 20,628 & 19,804 & 16,758 & 20,706 & 20,005 & 22,421 & 23,246 & 19,156 & 15,281 \\
Total & 34,67 & 30,777 & 32,815 & 39,173 & 36,773 & 39,364 & 41,955 & 33,565 & 26,985 \\
\hline
\end{tabular}

Data Source: Calculated based on the GTA database by the author.

\section{Literature Review and Research Method}

After the financial crisis in 2008, the impact of new trade protectionism on international trade aroused academic interest. Bown (2009) focused on trade relief measures, while Shingal (2009) analyzed the impact of trade protection measures on Japanese exports during the crisis [3] [4]. Henn and McDonald (2011) created a groundbreaking comprehensive assessment of the trade impact of broad protectionist measures during the financial crisis [5]. Most Chinese scholars focus on the impact of trade protectionism on China's trade since the recent financial crisis. Some scholars have carried out relevant descriptive analysis (Xue Rong-Jiu, 2009, Wang Li-Jun, 2010) [6] [7]. Although there are difficulties in data acquisition and method selection, a few scholars try to carry out theoretical analysis and empirical test. Wang Xiao-Mei (2014) tested empirically the effect of trade protectionism on China's export using dynamic first-differenced gravity equation based on GTA database and HS 4-digit level trade data [8].

According to the existing research results, this paper adopts the method of descriptive statistics analysis aiming at accurately analyzing the new trend of trade protectionism in the post-financial crisis era as well as the protection measures that China faced with.

\section{The New Trend of Global Trade Protectionism}

\subsection{The Dominant Player Turns from Developed Countries to Developing Countries}

Table 3 ranks the number of Global trade protective measures during the statistical period. The traditional trade protection theory holds that developed countries, as the high-end leaders of the value chain, occupy a favorable position in trade behavior. Compared with the low-end countries in the value chain, they tend to build trade barriers to protect their own interests. However, according to the statistics of more than 340,000 trade protection measures from the end of 2008 to 2018, the author found that among the ten countries that initiated the most trade protection, except for the United States, the EU countries occupy a considerable part, and the rest of India, Russia, China, and Brazil are all emerging developing countries. This trend indicates that the implementers of global trade protection measures are likely to shift from developed countries to developing countries. 
Table 3. Top 10 trade protection appliers.

\begin{tabular}{ccccc}
\hline & Green & Amber & Red & Total \\
\hline USA & 10,002 & 5335 & 35,029 & 50,366 \\
India & 6375 & 1623 & 17,758 & 25,756 \\
Russia & 5553 & 2875 & 13,178 & 21,606 \\
China & 8595 & 1603 & 9291 & 19,489 \\
Brazil & 9227 & 582 & 6996 & 16,805 \\
Germany & 2822 & 840 & 7824 & 11,486 \\
Malaysia & 5282 & 327 & 5821 & 11,430 \\
Argentina & 3912 & 588 & 6659 & 11,159 \\
Canada & 4158 & 1258 & 4565 & 9981 \\
Indonesian & 2909 & 941 & 4775 & 8625 \\
\hline
\end{tabular}

Data Source: calculated based on the GTA database by the author.

It is worth noting that although China ranks fourth in the world in terms of the total number of trade protection measures, this aspect is due to China's large trade volume, many trading partners, high participation in global value chains, and more likely to generate trade frictions. The measures to safeguard their own interests, on the other hand, can be seen that China's red coded measures that harm the interests of other countries account for only $47.6 \%$ of all measures. It can be said that most of China's measures are not or less harmful. On the contrary, the red measures taken by the United States and India accounted for $69.5 \%$ and $68.9 \%$, which is in stark contrast to China.

\subsection{China Is the Biggest Victim}

From the data of ten years in Table 4, developed countries are both the leader of trade protection and the main targets for implementation of these measures. However, from a single country, China is ahead of the United States and other countries with 8,118 measures among the 10 countries that have been targeted by trade protection measures. It can be seen from the table that China is the biggest victim of trade protectionism, whether it is amber or red, and its trade interests are seriously damaged.

\subsection{A Wide Variety of Trade Protection Measures}

According to the classification of GTA, these measures can be divided into state aid, competitive devaluation, consumption subsidies, export subsidies, export taxes or restrictions, import bans, import subsidies, intellectual property protection, investment measures, local content requirements, immigration measures, public procurement, health and quarantine measures, technical barriers to trade, tariff measures, trade remedies, non-tariff barriers, quotas, trade finance, and others (The 11th GTA Report, 2012) [9].

Table 5 shows that traditional tariff barriers are still the most commonly used 
Table 4. Top 10 trade protection victims.

\begin{tabular}{cccc}
\hline & Amber & Red & Total \\
\hline China & 1247 & 6871 & 8118 \\
USA & 697 & 4328 & 5025 \\
Germany & 543 & 4140 & 4683 \\
India & 652 & 3739 & 4391 \\
Italy & 466 & 3849 & 4315 \\
France & 459 & 3640 & 4099 \\
Japan & 554 & 3512 & 4066 \\
Korea & 493 & 3499 & 3992 \\
Canada & 481 & 3471 & 3952 \\
UK & 433 & 3498 & 3931
\end{tabular}

Data Source: calculated based on the GTA database by the author.

Table 5. Statistics of specific measures.

\begin{tabular}{|c|c|}
\hline Import tariff & 107,284 \\
\hline Bailout/State aid & 51,582 \\
\hline Public procurement & 26,211 \\
\hline Export Taxes or Restriction & 25,672 \\
\hline Export Incentive & 24,894 \\
\hline Migration Measure & 24,202 \\
\hline Non-Tariff Measure (not otherwise specified) & 22,257 \\
\hline Trade Defense Measure (AD, SG, CVD) & 15,547 \\
\hline Trade Finance & 14,598 \\
\hline Quota (incl. Tariff-Rate Quote) & 14,060 \\
\hline Localization Requirement & 6688 \\
\hline Import Ban & 2538 \\
\hline Investment Measure & 2225 \\
\hline Instrument unclear & 1494 \\
\hline Import Subsidy & 672 \\
\hline Technical Barrier to Trade & 540 \\
\hline Competitive Devaluation & 408 \\
\hline Sanitary and Phytosanitary Measure & 367 \\
\hline Consumption Subsidy & 179 \\
\hline Intellectual Property Protection & 118 \\
\hline Total & 341,536 \\
\hline
\end{tabular}

Data Source: calculated based on the GTA database by the author. 
means of trade protection, but in terms of quantity, the ratio is less than one-third. In addition to administrative measures and trade remedy measures that directly affect import and export, such as anti-dumping measures, national aid and trade financing and other measures that indirectly affect trade through other means are also worthy of attention.

\subsection{Products of Iron or Steel Is the Most Affected Department}

Table 6 shows interventions in the inspect of department. From the perspective of the industry, trade protection occurs mostly in industries with less global industry linkages. In the era of economic globalization, the international production network has been formed and expanded, making the economy of all countries "difficult to divide". "One glory and one loss" has made trade protection more rational among countries. The frequency of global trade protection in different industries is closely related to the industry's global relevance. In general, trade protection occurs mostly in industries with less global relevance.

The above describes the relationship between industry linkage and trade protection, but further from the perspective of industry, this trend is more obvious. The office equipment and computer industry, radio, television and communication equipment industries have high foreign intermediate use rates, so the global value chain is highly correlated. In contrast, the basic chemicals industry, the base metal products industry, agriculture and meat the agricultural products industry such as fish, fruits and vegetables have a low degree of relevance.

\section{New Trade Protectionism Facing China}

\subsection{The Total Amount of Trade Protection Measures Has Declined}

As mentioned above, China is the biggest victim of global trade protectionism. Table 7 demonstrates that from the total number of trade protection measures,

Table 6. Statistics of involving industries.

\begin{tabular}{cc}
\hline Industry & Interventions \\
\hline Products of iron or steel & 1123 \\
Motor vehicles, trailers and semi-trailers; parts and accessories thereof & 866 \\
Other fabricated metal products & 849 \\
Basic iron and steel & 571 \\
Electrical energy & 550 \\
Machinery for mining, quarrying and construction, and parts thereof & 535 \\
Aircraft and spacecraft, and parts thereof & 482 \\
Other general-purpose machinery and parts thereof & 463 \\
Agricultural or forestry machinery and parts thereof & 443
\end{tabular}

Data Source: calculated based on the GTA database by the author. 
Table 7. The number of protectionist measures China has suffered (2008-2018).

\begin{tabular}{cccccccccccc}
\hline & 2008 & 2009 & 2010 & 2011 & 2012 & 2013 & 2014 & 2015 & 2016 & 2017 & 2018 \\
\hline Green & 26 & 295 & 246 & 292 & 391 & 377 & 360 & 356 & 345 & 296 & 175 \\
Amber & 9 & 133 & 158 & 144 & 69 & 128 & 149 & 115 & 90 & 131 & 121 \\
Red & 250 & 820 & 681 & 706 & 740 & 703 & 694 & 672 & 669 & 542 & 375 \\
Total & 285 & 1248 & 1085 & 1142 & 1200 & 1208 & 1203 & 1143 & 1104 & 969 & 671 \\
\hline
\end{tabular}

Data Source: calculated based on the GTA database by the author.

China is far more than other countries, and the red and yellow measures that infringe on economic interests account for the vast majority. Most, From a trend perspective, the trend of China's trade protection impact is basically similar to the overall situation of the world. In 2009, as the first year of economic recovery after the financial crisis, China suffered the most serious trade protection, and this situation continued until 2016. After that, the number of measures to encounter trade protection began to decline significantly. As of the end of 2018, the number of trade protection measures in China has reached 671, of which 375 and 121 are red and yellow, respectively. The trade protection situation seems to have improved with the economic recovery in recent years.

\subsection{Distribution of Trade Protection Measures}

From November 2008 to December 2018, China suffered a total of 11,277 discriminatory trade protection measures from 142 countries around the world. Table 8 shows the number of countries in the top ten protection measures and the number of measures they have implemented. It can be found that there are developed countries and economies such as the United States and the European Union, as well as emerging developing economies such as Brazil, Russia and India. Developing countries are the main source of discriminatory trade protection measures in China, and about 8000 projects have been implemented, accounting for about $65 \%$. Among them, the most important source is the other countries with China's BRICS countries, Brazil, Russia and India. In contrast, the measures initiated by developed countries accounted for only about 35\%. In addition to the absolute dominant position of the United States, the source countries are mainly concentrated in the EU countries, and the most implemented measures are Germany (404). As the leader of the world economic order, the United States is the main promoter of new trade protectionism after the financial crisis. It is not surprising that China has launched a large-scale trade barrier against its hegemonic position. In contrast, developing countries have initiated China. Trade protection measures deserve special attention.

\subsection{Distribution of Trade Protection Measures}

The 20 discriminatory trade protection measures counted in the GTA database are all involved in China, and the distribution of the main measures is basically similar to the global situation. Trade protection measures against China can be 
Table 8. Statics of source of trade protection measures facing China.

\begin{tabular}{cc}
\hline & Implementing Jurisdiction \\
USA & 1264 \\
Brazil & 646 \\
India & 598 \\
Argentina & 564 \\
Germany & 481 \\
Indonesian & 404 \\
Malaysia & 300 \\
Italy & 298 \\
UK & 248 \\
France & 244 \\
South Africa & 241 \\
Poland & 237 \\
Canada & 210 \\
\hline
\end{tabular}

Data Source: calculated based on the GTA database by the author.

broadly divided into direct measures, indirect measures and other measures. Direct measures are the impact of goods under the tariff line of China on the export of the countries that implement the measures, including the increase in tariffs of exporting countries, trade remedy measures, etc.; indirect measures are measures implemented by foreign countries to support domestic exports or to promote The impact of measures of trade with a particular country on Chinese exports, including state aid, import and export subsidies, and trade finance; other measures are measures that do not directly affect the import and export of goods, including investment measures, immigration measures, and others. The proportion of the three types of measures in all discriminatory measures is shown in Table 9.

Statistics show that the types and quantities of trade protection measures with direct impact are the most, indicating that the impact is large, and the types of measures that have indirect effects are small, but the number is large. Specifically, the traditional forms of protectionism - tariff measures and trade remedy measures-accounted for $76.8 \%$ of the damage or measures that would harm China's interests once implemented. Explain that although new forms of trade protection emerge in an endless stream, traditional protectionist tools remain the dominant form during the crisis.

\section{Conclusions and Counter Measures Recommendations}

Based on the World Trade Early Warning Statistics Database, this paper systematically analyzes the new trend of international trade protectionism after the 
Table 9. Statics of specific trade protection measures of China.

\begin{tabular}{|c|c|c|}
\hline & Row labels & Count item: Classification \\
\hline \multirow{14}{*}{ Direct measure } & Import tariff & 3443 \\
\hline & Trade Defense Measure (AD, SG, CVD) & 2732 \\
\hline & Non-Tariff Measure (not otherwise specified) & 585 \\
\hline & Quota (incl. Tariff-Rate Quote) & 569 \\
\hline & Export Taxes or Restriction & 519 \\
\hline & Public procurement & 498 \\
\hline & Localization Requirement & $76.8 \%$ \\
\hline & Import Ban & 85 \\
\hline & Technical Barrier to Trade & 16 \\
\hline & Sanitary and Phytosanitary Measure & 8 \\
\hline & Consumption Subsidy & 6 \\
\hline & Competitive Devaluation & 5 \\
\hline & Intellectual Property Protection & 1 \\
\hline & Bailout/State aid & 1393 \\
\hline \multirow{4}{*}{ Indirect measures } & Trade Finance & 439 \\
\hline & Export Incentive & 327 \\
\hline & Import Subsidy & 2 \\
\hline & Migration Measure & 355 \\
\hline \multirow[t]{3}{*}{ Other measures } & Investment Measure & $4 \%$ \\
\hline & Instrument unclear & 33 \\
\hline & Total & 11,277 \\
\hline
\end{tabular}

Data Source: calculated based on the GTA database by the author.

financial crisis and the trade protection situation facing China and draws the following conclusions:

1) The global economic recovery did not limit the spread and continuation of world trade protectionism as people expected. On the contrary, global trade protection measures increased at a faster rate, and it seems that trade protection is likely to become more and more severe. The global economy will still face the negative impact of protectionist measures for some time to come.

2) After the financial crisis, developed countries are still the leaders of global trade protection measures, but developing countries have significantly increased their trade protection measures, and may become the main implementers of global trade protection measures in the future. Moreover, the trade protection measures implemented by developing countries have a broader impact. Therefore, developing countries' increasing pursuit of trade protectionism and its negative effects should not be ignored.

3) There are many kinds of trade protection measures introduced by countries all over the world, among which trade defense measures, tariff measures and na- 
tional aid measures take the lead. At present, global trade protection measures affect several sectors, among which steel sector is the main victim of global trade protection measures. In terms of individual countries, China is the biggest victim. The number of protective measures China faces is far higher than that of other countries.

According the conclusions, this paper proposes the following policy recommendations for China to deal with new trade protectionism:

1) Adhere to the WTO rules to properly handle trade frictions and use international trade rules to safeguard their rights and interests. As an international multilateral trading system, WTO has played an important role in promoting global trade liberalization and is currently the most important multilateral trading system in the world. The WTO trading system rules are one of the main principles for handling international trade disputes. Compliance with and use of WTO rules to safeguard their legitimate rights and interests will play an important role in the development of enterprises and the recovery of the Chinese economy. China is the defender of the international order. Once it encounters unreasonable trade protection measures, it should actively resort to the WTO dispute settlement mechanism.

2) China should make full use of its rising economic power and status as a major trading nation, use the platform such as WTO, actively participate in the dialogue between the global economy and trade, strengthen communication and information exchange, coordinate positions, and clarify the actual situation of mutual measures or potential negative impacts, forming mutual pressure between countries, thereby achieving a relative balance of measures to curb trade protection, gradually changing the unfair and irrational international economic and trade order, building a dialogue mechanism for equal consultation, and following the principle of mutual benefit and win-win, resolve trade disputes and jointly resist trade protectionism.

3) Accelerating the construction of bilateral free trade zones will not only create opportunities for China's product exports, but also provide greater room for maneuver in response to global trade protectionism and reduce the negative impact of trade protectionism. As new trade protectionism rises further, the trade friction between China and other countries will show a trend of normalization, long-termination and complexity. While adhering to the reform and opening, China must integrate its own development and trading partners more closely, and form a deeper mutual benefit and win-win division of labor. Through regional economic cooperation and the establishment of bilateral free trade zones, improve the overall infrastructure construction of the region, improve logistics efficiency, open up blocking points that hinder the supply chain linkages in the region, improve regional interconnection and interoperability, and establish extensive and deep relationships with different countries and regions. Level and comprehensive economic and technological cooperation to achieve market diversification. 
4) Relying on external forces to force domestic reforms and deepen integration into the world economy through further reform and opening. In the past 40 years, the Chinese economy has achieved remarkable achievements in terms of growth and development. These achievements are closely related to China's reform and opening. At the current time, China's reform and opening to the outside world also has some new constraints, including the increasing loss of labor advantages, the rising space for technological upgrading, the suppression of developed countries, and the rigidity of domestic monopoly enterprises. These have made China it is very necessary to use external forces to force domestic reforms and deepen China's reform and opening.

5) Improve the independent innovation capability of enterprises. The use of standard promotion and standard innovation to promote technological innovation is an effective means for enterprises to deal with trade protection. Behind trade protection is fierce industrial competition and technological competition, and the essence of industrial and technological competition is the competition of technological innovation systems. Under the effective guidance and support of relevant state departments, enterprises will strengthen their own interests and strengthen their competitive advantages by leading or participating in the formulation of standards that are beneficial to them. Actively promote enterprise technology patenting, patent standardization, and standard licensing, improve the technical content and product quality of enterprises, promote the optimization and upgrading of related industries, and enhance the competitiveness of enterprises in the international market. Many trade protection measures are aimed at China's export commodities are not high-grade and technical level is backward. Enterprises should use resistance as a driving force, accelerate industrial upgrading, upgrade technology, accelerate the development of technology research and development capabilities, and develop core technologies with independent intellectual property rights. International Competitiveness.

To sum up, China must unswervingly deepen reforms and adhere to development, support the establishment and transformation of strategic emerging industries, continuously improve its "hard power", improve its position and voice in the global trading system, and maintain International economic and trade order. In this process, it is inevitable that there will be many obstacles to trade protectionism. Therefore, China must maintain a clear-headed and objective understanding, maintain its strategic strength, and, in accordance with the requirements of the spirit of the 19th National Congress of the Communist Party of China, based on the needs of China's social and economic development, plan to further promote the breadth of reform and opening. At the same time, we must participate in the formulation and implementation of international economic rules, establish and improve the government's early warning and response mechanisms, and at the same time build an enterprise response system for international trade frictions, and actively and proactively respond to new trade protectionism. 


\section{Conflicts of Interest}

The author declares no conflicts of interest regarding the publication of this paper.

\section{References}

[1] WTO (2010) Report to the TPRB from the Director-General on Trade-Related Developments.

[2] GTA (2009) The 1st GTA Report. http://www.globaltradealert.org/analysis

[3] Bown, C.P. (2009) The Global Resort to Antidumping, Safeguards, and Other Trade Remedies amidst the Economic Crisis. Effective Crisis Response and Openness: Implications for the Trading System. https://doi.org/10.1596/1813-9450-5051

[4] Shingal, A. (2009) The Impact of Cross-Border Discrimination on Japan Exports: A Sectoral Analysis. The 3rd GTA Report, The Unrelenting Pressure of Protectionism.

[5] Henn, C. and McDonald, B. (2011) Protectionist Responses to the Crisis: Damage Observed in Product-Level Trade. IMF Working Paper No. WP11139.

[6] Xue, R.J. and Yang, F.M. (2009) Characteristics, Hazards and Countermeasures of the Protectionism Triggered by the Global Financial Crisis. International Economics and Trade Research, 25, 4-7+88.

[7] Wang, L.J. and Zhou, S.J. (2010) Financial Crisis and Trade Protectionism. Intertrade, No. 6, 16-19.

[8] Wang, X.M. and Qin, X.Z. (2014) Effects of Trade Protectionism on China's Export since Financial Crisis. The Journal of Quantitative \& Technical Economics, 31, $20-36+85$.

[9] GTA (2012) The 11th GTA Report. http://www.globaltradealert.org/analysis 